\title{
Comparative Studies on Growth Performance of Heterobranchus bidorsalis (Geoffroy Saint-Hilaire, 1809) in Different Culture Facilities
}

\author{
Lord Tertese Angahar*
}

Department of Fisheries and Aquaculture, University of Agriculture P.M.B 2373 Makurdi, Nigeria

\begin{tabular}{ll}
\hline A R T I C L E I N F O & Research Article \\
Received 05 October 2016 \\
Accepted 02 February 2017
\end{tabular}

Keywords:

Heterobranchus bidorsalis

Fish production

Culture facilities

Growth

Aquaculture

Earthen ponds.

*Corresponding Author:

E-mail: lordlegs356@gmail.com

\begin{abstract}
A B S T R A C T
Total catches of fish from the wild reached a plateau in the early 1990s. Capture fishery production for both food and non-food utilization has levelled off. There is need for aquaculture expansion and improved output. The aim of this study was to determine the most productive facility for production of Heterobranchus bidorsalis. H. bidorsalis is the most important species from the genus Heterobranchus. It is endemic to Africa. Seven hundred $H$. bidorsalis fingerlings were acclimatized for 7 days, 200 fingerlings were randomly selected and stocked in: Earthen ponds, Concrete tanks, and Plastic tanks labelled as T1, T2 and T3 respectively. Each treatment had two replicates, 100 fingerlings in each. The culture facilities were constructed to have water volume which was not significantly different. The earthen ponds, concrete and plastic tanks water volume was maintained at 2,320 litres, 2,304 litres, and 2,331 litres respectively. Fingerlings were fed with $2 \mathrm{~mm}$ Coppens of $45 \%$ crude protein at $5 \%$ biomass. Feeding was carried out at 9:00 and 16:00 hours for 56 days. All treatments were given equal care. Final Standard Length, Final Total Length, Total Length Gain, Final weight Gain and Weight Gain recorded were: $13.04 \pm 0.57,13.44 \pm 0.75,32 \pm 0.96,4.45 \pm 1.34,30.36 \pm 1.13$ and $23.34 \pm 2.4$ respectively. Growth was significantly higher in T1. In concrete and plastic tanks, observed growth parameters recorded had the following values: $11.75 \pm 0.82$ and $11.21 \pm 0.83,12.31 \pm 0.85$ and $11.95 \pm 0.89,3.2 \pm 0.96$ and $2.84 \pm 0.85,22.24 \pm 2.78$ and 21.24 \pm 5.84 , and $14.85 \pm 1.7$ and $14.99 \pm 1.02$ for Final Standard Length, Final Total Length, Total Length Gain, Final Weight and Weight Gain respectively. There was no significance difference in growth between $\mathrm{T} 2$ and $\mathrm{T} 3$. The study did not discourage the use of concrete tanks and plastic tanks for $H$. bidorsalis culture, but considered earthen ponds as most ideal culture facility for yields optimization in $\mathrm{H}$. bidorsalis.
\end{abstract}

\section{Introduction}

Fish, a major product of aquaculture is an important source of protein for the teaming population in developing nations. Fish and fishery products play a critical role in global food security and the nutritional needs of people in developing and developed countries (FAO, 2014). Food fish significantly improves our health (FAO, 2014).

Globally, fish account for about $17 \%$ of intake of animal protein (FAO, 2014). This share, however, can exceed $50 \%$ in some countries. In West African coastal countries, where fish has been a main element in local diet, the proportion of dietary proteins that comes from fish is very high. Fish account for more than $60 \%$ protein intake in Nigeria (Adekoya and Miller, 2004), 43\% in Senegal, 72\% in Sierra Leone, and 55\% in Gambia and Ghana (FAO, 2013). The same picture is seen for some Asian countries and small Island states, where the contribution from fish as protein source is also significant. In Maldives, fish contributes up to $70 \%$ of dietary protein, $60 \%$ in Cambodia, $57 \%$ in Bangladesh, $54 \%$ in Indonesia and $55 \%$ in Sri Lanka (FAO, 2013).
World Fish Center (2003), observed that total catches of fish from the wild reached a plateau in the early 1990s. Capture fishery production for both food and non-food utilization has leveled off. Per capital food fish supply from capture fisheries has actually declined during the last decade (FAO, 2000). FAO (2010), also reported that the maximum wild capture fisheries potential from the world's oceans has probably been reached. Capture fishery production is relatively static since the late 1980's (FAO, 2016). Meeting the ever-growing demand for fish as food due to world population growth, health and economic factors is challenging. There is need for the expansion of aquaculture and improvement in aquaculture productive facility for the production of Heterobranchus bidorsalis. The objective of the study was to increase culture fish production.

The genus Heterobranchus belongs to the family Clariidae (Tuegels et al., 1990), which consist of a second genus, Clarias. These two important genera have some similarities and are endemic to Africa (Madu et al., 1999). output. The aim of this study was to determine the most 
Teugels et al. (1990), reported that the genus Heterobranchus has four known species namely: Heterobranchus bidorsalis (Geoffroy Saint-Hilaire, 1809), H. longifilis (Valenciennes, 1840), H. boulengeri (Pellegrin, 1922) and H. isopterus (Bleeker, 1863).

The African giant catfish Heterobranchus bidorsalis is endemic to Africa and the most important species from the genus Heterobranchus used for aquaculture in Nigeria. The fish is on high demand because of its large size, palatable taste, high in oil content and it is less bony. Morphologically, $H$. bidorsalis has its head very strongly depressed, with a rectangular dorsum, and it carries a granulated upper surface. The adipose fin is short and soft, 0.4-0.67 times as long as the rayed dorsal fin, and about the same height. The dorsal fin is long and has 3845 rays, while the anal fin has 50-59 rays. The caudal fin is relatively long and slightly pointed. The snout is round and eyes lateral (Fagbenro et a1., 1991). The body and fins may have spots (Froese and Pauly, 2011). The colour is yellow-brown or dark olive above the whitish on the belly. The dorsal, adipose and caudal fin are brick (or tinted), red especially near the edge. The upper lips are also reddish. The barbels are grey, sometimes white near the edge (Tugels et al., 1991). H. bidorsalis can attain a total length (TL) of $1.5 \mathrm{~m}$, and a body weight of $30 \mathrm{~kg}$, which is highest, recorded.

\section{Materials and Methods}

Seven hundred $H$. bidorsalis pure breed fingerlings used for the study were obtained from a private fish hatchery. After an acclimatization period of 7 days, 100 fingerlings were randomly selected and stocked in three prepared different culture facilities: Earthen ponds, Concrete tanks, and Plastic tanks labelled as T1, T2 and T3 respectively. Each treatment had two replicates.

The concrete tanks both were measured $2.40 \mathrm{~m} \mathrm{x}$ $1.60 \mathrm{~m} \times 1.0 \mathrm{~m}(\mathrm{~L} \times \mathrm{b} \times \mathrm{h})$. Water level was maintained in the two replicates at $0.60 \mathrm{~m}$, given a water volume of 2,304 liters for each concrete tank. The plastic tanks were both measured $1.50 \mathrm{~m} \times 8.0 \mathrm{~m}$ (diameter $\times \mathrm{h}$ ). Water level was maintained in both at $0.33 \mathrm{~m}$ to obtain a total water volume of 2,331 liters for each plastic tank. The earthen ponds used had the given dimensions $2.0 \times 2.0 \times 1.0(\mathrm{~L} \times \mathrm{b}$ $\times$ depth). Water level was maintained at $0.58 \mathrm{~m}$ to have a total water volume of 2,320 in each earthen pond (replicate). The volume of water in all the treatments was not significantly different. The fingerlings were fed with $2 \mathrm{~mm}$ coppens, a commercial feeds with $45 \%$ crude protein at $5 \%$ biomass, divided into two rations. Feeding was carried out at 9:00 and 16:00 hours for 56 days. All treatments were given equal care.

\section{Determination of Water Quality Parameters}

The water quality parameters (Temperature, $\mathrm{pH}$ and Dissolved oxygen) were observed and recorded weekly for eight weeks (56 days). Graduated laboratory mercury in- glass thermometer $\left(0^{\circ}-100^{\circ} \mathrm{C}\right), \mathrm{pH}$ meter (model Jenway 3150) and Dissolved oxygen meter (YSI model 57) were used to determine temperature, $\mathrm{pH}$ and dissolved oxygen respectively.

Determination of Growth Parameters
A sensitivity weighing scale (Ek-300i) and a ruler were used to measure increase in weight and length of $H$. bidorsalis fingerlings respectively.

The following parameters were evaluated from the biological performance of test fish

- $\quad$ Mean Weight Gain (MWG) (g)

$\mathrm{MWG}=\mathrm{W}_{2^{-}}-\mathrm{W}_{1}$

Where;

$\mathrm{W}_{2}$ :mean final weight

$\mathrm{W}_{1}$ :mean initial weight (Okoye et al., 2001).

- $\quad$ Percentage Body Weight Gain (\% WG)

$\mathrm{WG} \%=\mathrm{W}_{\mathrm{t}}-\mathrm{W}_{\mathrm{o}} \times 100$

Where;

$\mathrm{W}_{\mathrm{o}}$ :Weight at the start of experiment (time ${ }_{\mathrm{o}}$ )

$\mathrm{W}_{\mathrm{t}}$ :Weight at the end of experiment (time ${ }_{t}$ )

- Mean Standard length gain MSLG (g)

$\mathrm{MSLG}=\mathrm{Sl}_{2}-\mathrm{Sl}_{1}$

Where;

$\mathrm{Sl}_{2} \quad$ :Final standard length

$\mathrm{Sl}_{1} \quad$ :Initial standard length

- $\quad$ Mean Total Length Gain MTLG (g)

$\mathrm{MTLG}=\mathrm{Tl}_{2}-\mathrm{Tl}_{1}$

Where;

$\mathrm{Tl}_{2} \quad$ :Final mean total length

$\mathrm{Tl}_{1}$ :Initial mean total length

$\mathrm{SGR}=\frac{\log _{\mathrm{e}} \mathrm{Wt}_{2}-\log _{\mathrm{e}} \mathrm{Wt}_{1}}{\mathrm{~T}_{2}-\mathrm{T}_{1}} \times 100$

Where;

$\mathrm{W}_{2}$ :Final weight at time $\mathrm{T}_{2}$

$\mathrm{W}_{1}$ :Initial weight at time $\mathrm{T}_{1}$

$\mathrm{T}_{2}-\mathrm{T}_{1}$ : Duration of the experiment (Days)

e :Natural logarithm (Jobling, 1994; Cui and Xie 2000; Alanara et al., 2001).

- Condition factor $(\mathrm{k})$

$\mathrm{K}=100 \mathrm{~W} / \mathrm{L}_{3}$

Where;

W :Weight of fish (g)

L :Length (Standard length) of fish $(\mathrm{cm})$ (Bagenal and Tesch, 1978).

- $\quad$ Survival rate $(\%)$

$\mathrm{S}=\mathrm{N}_{1} \times 100 / \mathrm{N}_{\mathrm{o}}$

Where;

$\mathrm{N}_{\mathrm{o}}$ :Number of fish at the start of experiment

$\mathrm{N}_{1}$ :Number of live fish at the end of experiment (Alatise and Otubusin, 2006).

Data Analysis 
Growth performance data from T1, T2 and T3 was analyzed statistically with Analysis of Variance ANOVA at $95 \%$ confidence level.

\section{Results and Discussion}

Observation on growth performance parameters and survival rates of $H$. bidorsalis fingerlings recorded from the T1, T2 and T3 is presented in Table 1. There was appreciable growth in all the culture facilities, however, highest growth was observed from the earthen ponds. The Final Standard Length, Final Total Length, Total Length Gain, Final weight Gain and Weight Gain recorded were:
$13.04 \pm 0.57,13.44 \pm 0.75,32 \pm 0.96,4.45 \pm 1.34,30.36 \pm 1.13$ and $23.34 \pm 2.4$ respectively. The growth was significantly $(\mathrm{P}<0.05)$ higher in $\mathrm{T} 1$ (earthen ponds).

In Concrete and Plastic tanks, observed growth parameters recorded had the following values: $11.75 \pm 0.82$ and $11.21 \pm 0.83,12.31 \pm 0.85$ and $11.95 \pm 0.89,3.2 \pm 0.96$ and $2.84 \pm 0.85,22.24 \pm 2.78$ and $21.24 \pm 5.84$, and $14.85 \pm 1.7$ and $14.99 \pm 1.02$ for Final Standard Length, Final Total Length, Total Length Gain, Final Weight and Weight Gain respectively. There was no significance difference $(\mathrm{P}>0.05)$ in growth between $\mathrm{T} 2$ (Concrete tanks) and T3 (Plastic tanks).

Table 1 Statistical Analysis on Growth Performances of H. bidorsalis in different culture facilities

\begin{tabular}{l|ccc}
\hline \multicolumn{1}{c|}{ Parameters } & Earthen pond (mean \pm SD) & Concrete tank (mean \pm SD) & Plastic tank (mean \pm SD) \\
\hline No. of fingerlings & 200 & 200 & 200 \\
Initial total length $(\mathrm{cm})$ & $9.11 \pm 0.86$ & $9.11 \pm 0.86$ & $9.11 \pm 0.86$ \\
Final total length $(\mathrm{cm})$ & $13.44 \pm 0.75$ & $12.31 \pm 0.85$ & $11.95 \pm 0.89$ \\
Total length gain $(\mathrm{cm})$ & $4.45 \pm 1.34$ & $3.2 \pm 0.96$ & $2.8 \pm 0.85$ \\
Initial standard length $(\mathrm{cm})$ & $8.7 \pm 0.39$ & $8.7 \pm 0.39$ & $8.7 \pm 0.39$ \\
Final standard length $(\mathrm{cm})$ & $13.04 \pm 0.57$ & $11.75 \pm 0.82$ & $11.21 \pm 0.83$ \\
Initial weight $(\mathrm{g})$ & $7.02 \pm 1.11$ & $7.02 \pm 1.11$ & $7.02 \pm 1.11$ \\
Final weight $(\mathrm{g})$ & $30.36 \pm 1.13$ & $22.24 \pm 2.78$ & $21.24 \pm 5.84$ \\
Weight gain $(\mathrm{g})$ & $23.34 \pm 2.4$ & $14.85 \pm 1.7$ & $14.99 \pm 1.02$ \\
Weight gain $(\%)$ & 432.48 & 300.95 & 339.84 \\
Specific growth rate $\left(\%\right.$ day $\left.^{-1}\right)$ & 2.9 & 2.2 & 2.4 \\
Condition factor $(\mathrm{k})$ & 1.37 & 1.37 & 1.50 \\
Survival rate $(\%)$ & 97 & 95 & 92 \\
\hline
\end{tabular}

Values are as means \pm SD

Table 2 Means and range value of observed water quality parameters

\begin{tabular}{l|ccc}
\hline \multicolumn{1}{c|}{ Parameters } & Earthen pond (mean \pm SD) & Concrete tank (mean \pm SD) & Plastic tank (mean \pm SD) \\
\hline pH & $7.20 \pm 0.01-6.90 \pm 0.02$ & $8.10 \pm 0.01-7.4 \pm 0.02$ & $7.30 \pm 0.03-6.58 \pm 0.04$ \\
DO $(\mathrm{mg} / \mathrm{l})$ & $6.76 \pm 0.04-5.27 \pm 0.01$ & $6.70 \pm 0.02-6.13 \pm 0.01$ & $6.25 \pm 0.03-5.10 \pm 0.01$ \\
Temp $\left({ }^{\circ} \mathrm{C}\right)$ & $26.8 \pm 0.02-26.0 \pm 0.01$ & $28.1 \pm 0.03-26.1 \pm 0.01$ & $28.8 \pm 0.03-26.5 \pm 0.02$ \\
\hline
\end{tabular}

Values are as mean \pm SD

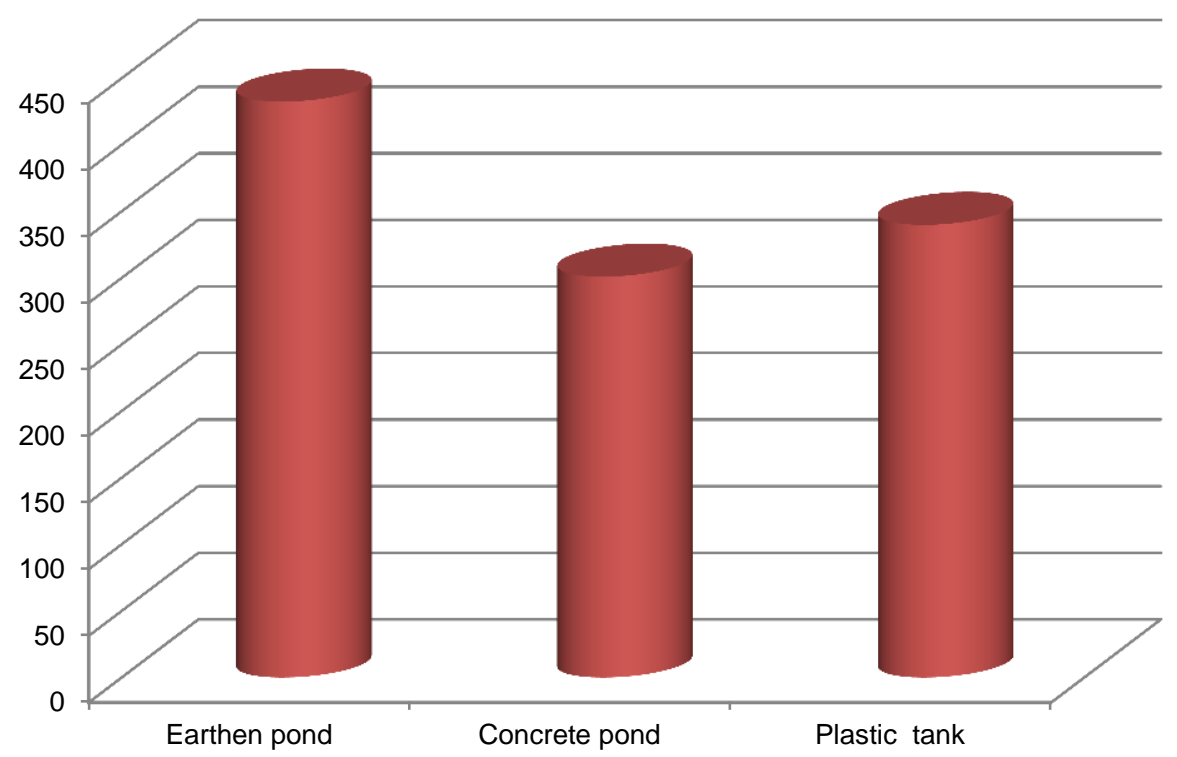

Figure 1 Percentage weight gain of H. bidorsalis in T1 (Earthen pond), T2 (Concrete tank) and T3 (Plastic tank) 
Figure 1 gives percentage weight gain of $H$. bidorsalis. The percentage weight gain was $432.48 \%$ in earthen ponds, $300.95 \%$ in concrete tanks, $339.84 \%$ in plastic tanks. The condition factor $(\mathrm{K})$ was 1.37 in both earthen ponds and concrete tanks, and 1.50 in plastic tanks. Culture organism in earthen ponds had a survival rate of $97 \%$, while those in concrete and plastic tanks had survival rates of $95 \%$ and $92 \%$ respectively. Specific growth rate was $2.9 \%, 2.2 \%$ and $2.2 \%$ for earthen, concrete and plastic culture facilities.

The means and range values of $\mathrm{pH}$, Dissolved oxygen (mg/l) and temperature ${ }^{\circ} \mathrm{C}$ observed from the culture facilities as shown in Table 2 was not significantly $(\mathrm{P}>0.05)$ different

Heterobranchus bidorsalis fingerlings reared in all the three treatments showed a positive progressive growth with appreciable increase in body mass and lengths. However, $H$. bidorsalis fingerlings in earthen ponds gained more growth than those in concrete and plastic tanks. The higher growth and survival rate obtained from earthen ponds was attributed two major factors: The microbial properties of the earthen ponds and the presence of natural food organisms. The soil to which formed the earthen pond is a home to billions of microorganisms Stehouwer (2009), which include autotrophs, saprophytes, heterotrophs, chemotrophs, nitrifying and denitrifying bacteria and host of others. A consortium of the pond microorganisms work synergistically for the welfare of fish. Angahar (2016), observed that some of the microorganism have the ability to improve pond water quality. Santos (2002), wrote that in converting ammonia $\left(\mathrm{NH}_{3}{ }^{+}\right)$into nitrite $\left(\mathrm{NO}_{2}^{-}\right)$by nitrifying bacteria the level of toxic compounds is significantly reduce to safer levels for the aquaculture organism. Thus, organic waste is reduced, and dissolved oxygen levels are increased through the activities of phytoplankton. This optimization of pond water quality by microorganism is translated to the improved fish growth as observed in $H$. bidorsalis grown in earthen ponds. Naturally, microbial population and diversity is higher in earthen ponds than concrete or plastic tanks.

Fish live food organisms is much predominate in earthen ponds than concrete or plastic tanks. The live food which ranges from micro-fauna to macro-fauna greatly supplements fish nutrition. The abundance of plankton in earthen pond also directly supplements the diet of fish, or indirectly improves the aquatic food chain to which the fish is the ultimate beneficiary. $H$. bidorsalis fingerlings showed far excellent growth performance because of the accounted reasons. Concrete and plastic tanks often have low microbial population and diversity in contrasts to that of earthen ponds, hence their lower recorded growth performances. Beneficial microbial population is often very low in plastic tanks because of absence of suitable substrate or microbial habitat.

Adebayo and Adesoji (2008), in comparative assessment of the profit margin of catfish reared in concrete tanks and earthen ponds, also obtained higher average weight gain from earthen ponds. This result concurs with Keremah and Esquire (2014), study which reported higher yields of $3.0 \mathrm{~kg}$ fish in pond than those in tanks $1.81 \mathrm{~kg}$.

\section{Conclusion}

The earthen pond, concrete and plastic tanks are suitable for $H$. bidorsalis production. The study did not discourage the use of such facilities for $H$. bidorsalis culture. Nevertheless, the earthen pond is the best, and the most ideal culture facility for yields optimization in $H$. bidorsalis culture. It offers $H$. bidorsalis better survival and growth rates, with the highest final weight gain.

\section{References}

Adebayo IA, Adesoji SA. 2008.Comparative Assessment of Profit margin of Catfish reared in concrete tank and earthen pond. African Journal of Agric. Res. 3 (10): 677-680

Adekoya BB, Miller JW. 2004. Fish cage culture potential in Nigeria- An overview. National cultures. Agricultural focus 1(5) 10

Alanara A, Kaaris S, Paspatis M. 2001. Feeding Management. In: Hoalihan D, Jobling M, Boujard, T. Feed intake in Fish. Oxford, UK: Black well Science, 332-353

Angahar LT. 2016. Applications of Probiotics in Aquaculture. Ajcmicrob 4 (1) 66-79 http://ivyunion.org/index.php/ajcmicrob

Bagenal TB, Tesch FW .1978. Age and Growth In: Bagenal. T. (Eds). Methods for Assessment of Fish Production in Fresh Waters, 3rd Edn. Oxford: Blackwell Scientific Publications. 101-136

Brown ME.1957. The Physiology of Fishes vol. 1. New York: Academic press Inc 44

Cui Y, Xie S. 2000. Modeling Growth in Fish. In: Theodorou, M.K and France, J (Eds). Feeding systems and Feed Evaluation Models. CAB International 413-434

Fagbenro OA, Olaniran TS, Esan OA. 1991. Some aspects of the biology of catfish, H. bidorsalis Geoffroy Saint-Hilaire, 1809 (Clariidae) in River Ogbese, Nigeria. J.Afr. Zool. 105: 363-372

FAO. 2016. The State of World Fisheries and Aquaculture. Contributory to Food security and nutrition for all. Rome: FAO Publication

FAO. 2014. The State of World Fisheries and Aquaculture: Opportunities and Challenges. Rome: Food and Agriculture Organization of the United Nation Press

FAO. 2013. Fish Trade and Human Nutrition. Rome. Food and Agriculture Organization of the United Nation Press.

FAO. 2010. Resumed Review Conference on the Agreement Relating to the conservation and Management of Straddling fish stocks and Highly Migratory Fish Stocks. Rome: FAO publication

FAO. 2000. Global Trends in Fisheries and Aquaculture. Rome: FAO Publication

Froese R, Pauly D. 2011. Heterobranchus bidorsalis. Fish base Available from: http:// fishbase [Accessed $8^{\text {th }}$, March,2015]

Jobling M. 1994. Fish Bioenergetics. London: Chapman and Hall

Keremah R.I, Esquire J. 2014. Comparative Assessment of Growth Performance and Economics of production of Clarias gariepinus fingerlings in Ponds and Tanks. Greener Journal of Agriculture Sciences 4 (2) 034-038 Doi: http//dx.doi.org/ 10.15580/GJAS. 2014.2.041513577

Madu CT. Ita EO. Mohammed S. 1999. Fishing Business in African Economy. Ibadan, Nigeria. Macmillan press 11-14

Okoye FC, Eyo AA, Aminu NG. 2001. Growth of Tilapia Oreochromis niloticus Hybrid Fingerlings Fed Lipid Based Diets. In: Eyo. A.A (Ed). Proc. of the 1st National Symp. on Fish Nutrition and Fish Feeds Tech of FISON, NIOMR Lagos, 26th Oct., 1999.FISON press.. 25-27

Santos G. 2002. Probiotics: An essential tool in intensive shrimp aquaculture. Biomin press 8: 4-5 